\title{
Challenges in Children's Literature Translation: a Theoretical Overview
}

\author{
Aida Alla, Ph.D Cand. \\ AAB Unversity \\ aida.alla@universitetiaab.com
}

\begin{abstract}
There is an increasing demand for translation of children's literature nowadays and this demand is accompanied by an increased need for the researchers to study the nature and feature of such a discipline. It is worth mention that the word "children's literature" in English-speaking countries is a broader term covering children, adolescents and sometimes young adults. The present paper aims to highlight some comprehensive theoretical aspects concerning children's literature translation. Special attention is paid to the issues which have generated lots of intense and ongoing debates among theoreticians as to which translation strategies and procedures would be more beneficial to the target language child reader. Before elaborating on such issues, this paper casts some light on the various definitions of children's literature and its characteristics, its status and the role it exerts on the potential readership. Ambivalence of children's literature - the texts being addressed to both children and adults - constitutes one of the biggest challenges for the author and the translator of children's literature alike. Such a phenomenon is investigated in this paper illustrated with some book titles. Another feature which is tackled in this paper is that of asymmetry, which refers to the unequal communication levels between adults and children. Finally, conclusions will be drawn regarding to most popular theoretical trends of children's literature and children's literature translation.
\end{abstract}

Keywords: children's literature, translation strategies, polisystem theory, scopos theory, ambivalence.

\section{INTRODUCTION}

There are some reasons behind the assumption that children's literature is a minor and peripheral literary form in many cultures, including Albania. According to Zohar Shavit, this is due to the fact that the emergence and development of children's literature have followed common patterns across different countries (1996: 27). This condition of inferiority derives from the history and tradition of this body of literature, which is strictly bound to those of childhood, representing a minority group that has historically suffered a status of inferiority and subordination to other groups.

Thus, the main system of literature tends not to attribute a high value to literature for children, which in turn, has resulted in minor literary research. The most evident repercussion of this peripheral status on the translation of books for children has been identified by many (Shavit, O'Sullivan, among others) in the marked tendency of translated children's books towards 'acceptability' introduced by Toury 'domestication' introduced by Venuti, or, in other words, Schleiermacher's well known principle of 'bringing the author towards the reader' (49).

The great freedom allowed to translators and/or editors, and the high degree of rewriting, abridging, adapting and other kinds of intervention that books for children have undergone, seem to derive from the specific attitude adopted towards the genre in the target context; the more this was considered peripheral, marginalized and of little literary merit, the more freedom seemed to be allowed in translating works for children. Klingberg in his book Children's Fiction in the Hands of Translators, states that the extent to which the characteristics of the young readers are taken into consideration can be referred to as degree of adaptation and it should be preserved in translation because the original should not change as far as level of difficulty or interest is concerned. (1986)

\section{DEFINITIONS OF CHILDREN'S LITERATURE}

There have been made several attempts on the part of the scholars to provide a unanimously accepted definition of what can be considered children's literature. There are scholars who even go so far as to question the existence of children's literature. As Jack Zipes (2001) puts it, in "Why Children's Literature Does Not Exist," "There has never been a literature 
conceived by children for children, a literature that belongs to children, and there never will be." Another researcher who raises the question whether there is a need to define children's literature at all is Riita Oittinen arguing that works of literature and whole literary genres acquire different meanings and are redefined again and again. It might therefore, well be that today's adults' literature is tomorrow's children's literature. (1993: 42,43) Gulliver's Travel proves this definition right. According to Klingberg, the term children's literature can refer to different concepts, such as literature recommended to children, literature read by children and literature published for them (2008:8).

The cultural concept of "children" and "childhood" also changes radically with time, place, gender, and perceiver, and so the corpus of texts ("children's literature") is unstable. Childhood two hundred years ago (and consequently the books designed for it) may seem so remote from current childhood and its texts that a distinction might be made between "historical children's literature", or books that were for children, and "contemporary children's literature," books that address or relate to recognizable current childhoods (P. Hunt 1996; Flynn 1997).

The body of texts can be seen as a symbiotic movable feast: the book defines its audience, which is children, and that in turn affects how children are generally defined as well as how they actually will be in the future. In this context, the term "children" is increasingly being interpreted as "comparatively inexperienced/unskilled readers." (Nell \& Paul: 2001: 43) Jacqueline Rose, who, in The Case of Peter Pan (1984), carefully uses the term "children's fiction," suggests that children's fiction is impossible, not in the sense that it cannot be written, but that it hangs on.... the impossible relation between adult and child....". Children's fiction sets up a world in which the adult comes first (author, maker, giver) and the child comes after (reader, product, receiver), but where neither of them enter the space in between. (ibid: 44)

\section{III.}

\section{CHARACTERISTICS OF CHILDREN'S LITERATURE}

Before we start to elaborate on the challenges of children's literature translation, it is essential to refer to some peculiarities and characteristics of children's literature as such. One of the characteristics of children's literature is its ambivalence due to the fact of its dual readership. To Rurvin and Orlati, ambivalent texts are those "written for and received by both adults and children at various textual levels of both production and reception" (2006: 159). This is a challenge to a translator and an issue of concern in children's literature translation. Quoting Metcalf: "More children's books than ever before address a dual audience of children and adults, which on the other hand comes with a dual challenge for the translator, who now has to address both audiences in the translated literature" (2003: 323). To preserve multiple levels in the text, the conventional one to be simply realized by the child reader; the other one only understandable to adults, is one of the biggest challenges for translators of children's literature. (Frimmelova 2010: 35) The Harry Potter saga is a very good illustration of an ambivalent text. Hundreds of pages and a seven-book compilation cannot be appealing to teenagers only. Not to mention the linguistic complexities and layers it encompasses due to the author's sophisticated style of writing.

Asymmetry is another feature of children's literature which entails the relationship between the writers who are adults and the readers who are children. When the partners in communication are not equal, communication structures are asymmetric. Children's literature differs from adults literature in that the authors of children's books and their audience have a different level of knowledge and experience. It is adults who decide on the literary form and it is they who decide what to publish and what to sell without giving the children a chance to decide for themselves.

Another important characteristic of children's literature seen from the pedagogical viewpoint is to educate the child reader. As Puurtinen points out, adults expect children's literature to help in the development of the child's linguistic skills. Therefore, there might be a stronger tendency for authors and translators of children's literature to normalize the texts by grammaticising them, in order to avoid the readership learning faulty grammar from the books. (Puurtinen: 1998)

\section{THEORETICAL ASPECTS OF CHILDREN'S LITERATURE TRANSLATION:}

There are two main trends of translation procedure: source oriented translation and target oriented translation. The first approach advocates the preservation of the source language and cultural characteristics (being faithful to the form and meaning) whereas the latter favors the "merging" of source text into the target language culture, bringing it closer to the readership. Instead of aiming at an adequate translation, the translator should aim at an acceptable translation considering the fact that children's reading abilities are not as advanced as the adults' and their knowledge of the world is limited. "It is 
the task of the translator to decide how she/he will compensate for the children's lack of background knowledge without oversimplifying the original and forcing children into simple texts that have lost any feature of difficulty, foreignness, challenge and difficulty". (Ztolze 2003: 209)

In the late 1980s, Klingberg, in his Children's Fiction in the Hands of the Translators, criticized what he perceived as the most common way to translate books for children. In his view, the main aim of this activity should be that of enriching the reader's knowledge and understanding of foreign cultures. Yet, most translators' interventions on the source texts what he categorizes as 'cultural context adaptations', 'purifications' 'modernizations', 'abridgements' and 'serious mistranslations' - hinder that aim. Klingberg suggested that translation strategies which tend to preserve the foreign spirit of the originals should be preferred, so that the child-reader can get acquainted with the country and the culture from where those books come.

Zohan Shavit has given important contribution to the translation of children's literature in that she utilized the polysystem theory introduced by Itamar Evan-Zohar to explain the translational pattern of children's literature. Polysystem theory had a strong impact on research into translation of children's literature, because it elevated a genre regarded as minor to a central object of research. "The polysystem is conceived as a heterogeneous, hierarchized conglomerate of systems which interact to bring about an ongoing, dynamic process of evaluation within the popysystem as a whole. Evan Zohar' polysystem theory places literature in two positions: in the center and periphery. The closer to the periphery the lower the cultural status of the subsystem is within the polysystem. Translated literature constitutes one of the subsystems and it might position itself either in the center representing a significant part of a country's literature or remaining in the periphery and imposing less influence." (Baker, 1998: 176)

According to Shavit, unlike contemporary translators of the adults' books, the translator of children's literature can permit himself great liberties regarding the text as a result of the peripheral position of the children's literature within the polysystem. That is, the translator is permitted to manipulate the text in various ways by changing, enlarging or abridging it or by deleting or adding to it. (1986: 111) "In viewing translation as part of a transfer process, it must be stressed that the subject at stake is not just translations of texts from one language to another, but also the translations of texts from one system to another -- for example, translations from the adult system into the children's." (Shavit 1986: 111)

Another translation theory that has given a great contribution to the translation process of children's literate is Vermeer and Reiss's Scopos theory. Scopos (purpose) of translation is the main criterion of this theory which shifted the attention from the course oriented approach to the target oriented procedures, thus putting the reader at the center of this process. As a result of this approach, the status and responsibilities of translator changed as well, having more freedom to resort to strategies which meet the children's special demands as the main readers. "The translator is "the" expert in translational action. He is responsible for the translational action". (Vermeer 223: 223) According to scopos theory, the translator is considered a "cultural product" and the process of translation "a culture-sensitive procedure". (Vermeer in Mary, and Kaindl: 1994). In the context of children's literature, scopos theory made significant changes to the status of translators, readers and the translation process.

\section{CONCLUSION}

The study of children's literature is a well established discipline and a lot of scholars are giving their contribution despite the wrong conception that children's literature is of less importance and less sophisticated than adults' literature. On the other hand, translation studies of children's literature are embryonic and only in the last two decades are theorists elaborating on the translation strategies with a focus on children as a target group and their reading competences and demands.

The primary aim of this paper has been to give an overall view of the subject on children's literature and its translation from the theoretical perspective. Even though an attempt has been made to give a panorama of current situation of this filed, it was impossible, due to the constraints and the length of this paper, to cover all the facets of this discipline.

However, it was concluded that there is no final definition of children's literature because of the wide range of topics, genres and elements it covers and the fact that this kind of literature is written by adults and addressed to children. There are 
scholars who believe that there is no such thing as children's literature due to the fact that the child reader is the passive actor who is offered everything that adults consider as appropriate for them.

As far as the characteristics of children's literature as concerned, it was observed that such texts are appealing to children as well as adults and such ambivalence constitutes one of the biggest challenges both for writers and translators. Asymmetry was another feature of children's literature which was highlighted in this paper. Asymmetry refers to the relationship between the writers who are adults and the readers who are children. Additionally, from the pedagogical viewpoint, the purpose of children's literature is to educate.

While analyzing the theoretical aspects of translation, it was observed that different theoreticians have different approaches as to whether preserve the culture of the source text during the translation process or simplify it and replace the culturebound word with their equivalents in the target language. Finally we must say that, no matter what strategy the translator resorts to, he/she must produce a text which conveys the elements of the unusual, but it must be acceptable and easy-toread-and-remember, without underestimating the children's knowledge about the world.

\section{REFERENCES}

[1] Frimmelova, K. (2010). Translating Children's Literature: diplomová práce. Brno: Masarykova univerzita, Fakulta pedagogická, Katedra anglického jazyka a literatury.

[2] Metcalf, E-M., (2003). ,Exploring Cultural Difference through Translating Children"s Literature", Meta, xviii, 1-2, pp. 32227.

[3] Phillip Nell, Lissa Paul. (2011) Keywords for Children's Literature, New York University Press, New York and London.

[4] Puurtinen, T. (1998) 'Syntax, readability and ideology in children's literature', Meta 43(4).

[5] Rudvin, M. \& Orlati, F. (2006) Dual Readership and Hidden Subtexts in Children"s Literature: The Case of Salman Rushdie"s Haroun and the Sea of Stories", in: van Coillie, Jan and Walter P. Verschueren (eds.), Children's literature in translation. Challenges and strategies, Manchester: St. Jerome Publishing, pp. 157-184.

[6] Oittinen, R. (1993) I am me - I am other: On the Dialogics of Transaltion for Children Vammalan, Kirjapaino Oy: University of Tampare.

[7] Klingberg, G. (2008) Facets of Children's Literature Research: Collected and Revised Writings.

[8] Svenska barnboksinstitutet, Stokholm.

[9] Shavit, Z. (1986) Poetics of Children's Literature, Athens and London, University of Georgia Press.

[10] Shavit Zohar. (1995) "The Historical Model of the Development of Children's Literature." Aspects and Issues in the History of Children's Literature. Ed. Maria Nikolajeva. London:Greenwood Press,. 27-38.

[11] Vermeer, H.J. (2000) Skopos and commission in translational action. In: Venuti: The translator's study reader. London, New York.

[12] Vermeer, H.J. (1994) Translation today: Old and new probmes". In: Translation Studies: An Interdiscipline, Snell Horby, Mary, and Klaus Kaindl, Benjaminn Library.

[13] Zipes. Jack. (2001) Sticks and Stones: The Troublesome Success of Children's Literature from Slovenly Peter to Harry Potter. New York: Routledge. 